\title{
Lipopolysaccharide (LPS) segmental lung challenge in nonhuman primates - a model of airway inflammation
}

\author{
Franklin J Schlerman*, Andrea G Bree, Michael D Wadanoli, Samuel J Goldman, Cara MM Williams, Joseph P Sypek \\ From 2nd Cross Company Respiratory Symposium \\ Horsham, UK. 6-7 September 2012
}

We developed a reproducible model of neutrophilic inflammation in cynomolgus monkeys (Macaca fascicularis) in order to study potential novel anti-inflammatory compounds intended for respiratory diseases such as COPD and asthma. Using a pediatric bronchoscope, a baseline bronchoalveolar lavage (BAL) was performed on the left lung prior to LPS segmental challenge to the right lung. At 24, 72 and 168 hours post challenge, BAL fluid (BALF) was collected to assess the level of pulmonary inflammation. At both 24 and 72 hours $(\mathrm{Hr})$ post LPS challenge, total BAL cells were significantly elevated over baseline. BAL cell differentials revealed that mean percent neutrophils significantly increased from baseline (1.3 $\pm 1.6 \%)$ to $(74.0 \pm 21.9 \%$ at $24 \mathrm{Hr}$ and $26.6 \pm 21.0 \%$ at $72 \mathrm{Hr}$ ) whereas, BAL macrophage numbers had significantly decreased from baseline $(94.4 \pm 3.1 \%)$ to (31.6 \pm $21.2 \%$ at $24 \mathrm{Hr}$ and $64.2 \pm 20.1 \%$ at $72 \mathrm{Hr}$ ) post challenge. In addition to increased inflammation, we also observed a significant increase in BAL cell gene expression of MMP-9 and significant increases in SCD14 and IL-8 from concentrated BALF $24 \mathrm{Hr}$ post challenge. Numbers of infiltrating cells and other inflammatory parameters returned to baseline levels by $168 \mathrm{Hr}$ following LPS challenge. In some studies, intramuscular injections of dexamethasone (Dex [ $1 \mathrm{mg} / \mathrm{kg}]$ ) were administered $24 \mathrm{Hr}$ prior and just prior to LPS challenge. Dex did not significantly reduce total BAL inflammation or IL-8 protein, but did significantly reduce percent neutrophils and $\mathrm{sCD} 14$ protein within the BALF 24 hours post challenge. Dex also significantly increased percent macrophages $24 \mathrm{Hr}$ post challenge. These data show that segmental challenge with LPS produces an acute pulmonary neutrophilic inflammation,

Inflammation and Remodeling Research, Pfizer Cambridge Massachusetts, 02140, USA

Submit your next manuscript to BioMed Central and take full advantage of:

- Convenient online submission

- Thorough peer review

- No space constraints or color figure charges

- Immediate publication on acceptance

- Inclusion in PubMed, CAS, Scopus and Google Scholar

- Research which is freely available for redistribution 